\title{
SEGMENTASI CITRA X-RAY THORAX MENGGUNAKAN LEVEL SET
}

\author{
Mokhamad Amin Hariyadi \\ Informatic Engineering Department, Faculty of Saintek, UIN Maulana Malik Ibrahim \\ Malang - Indonesia
}

\begin{abstract}
Abstrak - Untuk mengurangi kelemahan perhitungan cardiothoracic ratio (CTR) secara manual maka dilakukan perhitungan secara semi otomatis. Dalam menentukan cardiothoracic ratio secara semi-otomatis diperlukan segmentasi rongga dada yaitu organ paru-paru. Pada penelitian ini akan dilakukan segmentasi organ tersebut dengan menggunakan Geometric active contour (level set). Metode segmentasi ini dipilih, karena level set ini mampu berevolusi mengikuti penyebaran kurva, kurva akan berkembang dan berhenti pada batas obyek dalam suatu image.Penelitian ini diharapkan dapat menyediakan alat bantu (tool) medis untuk membantu penentuan nilai CTR secara semi-otomatis yang bisa digunakan untuk berbagai hal seperti screening masal citra X-ray, alat bantu radiographer di daerah atau di puskesmas untuk bisa secara dini melaporkan adanya indikasi penyakit jantung, instrumen praktis dan otomatis bagi ahli radiologi.Penelitian ini menggunakan 20 citra X-ray paru-paru.Untuk menguji kinerja dari metode yang diusulkan hasil segmentasi level set dibandingkan dengan segmentasi manual. Dan diperoleh hasil sensitifitas 93,36\%, akurasi 96,17\% dan spesifitas 96,78\% untuk paru-paru kiri serta sensitifitas 93,47\%, akurasi 95,88\% dan spesifitas 96,31\% untuk paru-paru.
\end{abstract}

Kata kunci: cardiothoracic ratio, citra x-ray, active contour, level set

\section{PENGantar}

Penyakit jantung merupakan penyebab nomor satu kematian di dunia. Di Indonesia angka kematian yang disebabkan serangan jantung mencapai 26 hingga 30 persen. Faktor risiko penyakit jantung koroner adalah kebiasaan merokok, stres, kurang olah raga, kencing manis atau diabetes, obesitas, hipertensi serta hiperlipidemia atau kelebihan lemak dalam darah, keturunan, usia, dan jenis kelamin.

Penyakit jantung merupakan pembunuh yang paling berbahaya saat ini. Penderitanya tidak mengenal kalangan, dapat berasal dari kalangan ekonomi tinggi sampai orang dari kalangan ekonomi lemah. Salah satu tanda penyakit ini adalah adanya pembesaran ukuran jantung atau yang disebut dengan cardiomegally. Jadi bisa dikatakan bahwa kalau terjadi pembengkakan ukuran jantung, maka hampir bisa dipastikan ada indikasi mempunyai penyakit jantung. Pemantauan pembesaran jantung selama ini masih menggunakan modaliti X-Ray karena modaliti ini hampir tersedia di hampir seluruh rumah sakit. Bahkan untuk kasus di Indonesia, banyak puskesmas yang sudah mempunyai peralatan ini. Sehingga tidak mengherankan, hampir empat puluh persen dari pemeriksaan radiologi yang menggunakan X-Ray (radiografi) merupakan pemeriksaan.

\section{METODE DAN CARA KERJA Akuisisi Citra X-ray}

Akuisisi Citara X-ray merupakan tahapan awal dalam penelitian ini, untuk lebih jelasnya dapat dilihat pada gambar 1 tentang tahapn pada penelitian ini. Secara umum struktur organ-organ pada rongga dada memiliki kesamaan, baik bentuk ukuran maupun letaknya, sehingga cukup 
sulit untuk melihat apakah terjadi keabnormalan dari organ-organ tersebut (Carrascal. 1998). Penelitian ini menggunakan 20 citra $X$-ray thorax dan segmentasi manualnya yang sudah tervalidasi di dalamnya (Ginneken, 2001). Ketelitian dari metode segmentasi thoracic $X$-ray ini sebesar $90 \%$ dasar observasi awal dari segmentasi manual, dan $86 \%$ pada observasi kedua. Selanjutnya melakukan perubahan image ke format yang diperlukan, image (citra) direpresentasikan dengan menggunakan metode level sets. Proses pembangunan level sets merupakan bentuk dari suatu connected component yang disimpan pada node yang digunakan untuk menyimpannya. Tahap selanjutnya melakukan filtering terhadap node-node dari level sets. Filtering menggunakan bentuk kurva tertutup (Dryden, 1998). Node-node yang menyimpan bentuk selain bentuk tersebut akan dihapus dari level sets. Tahap terakhir adalah pembangunan kembali citra dari level sets yang sudah terfilter (Chunming, 2005)

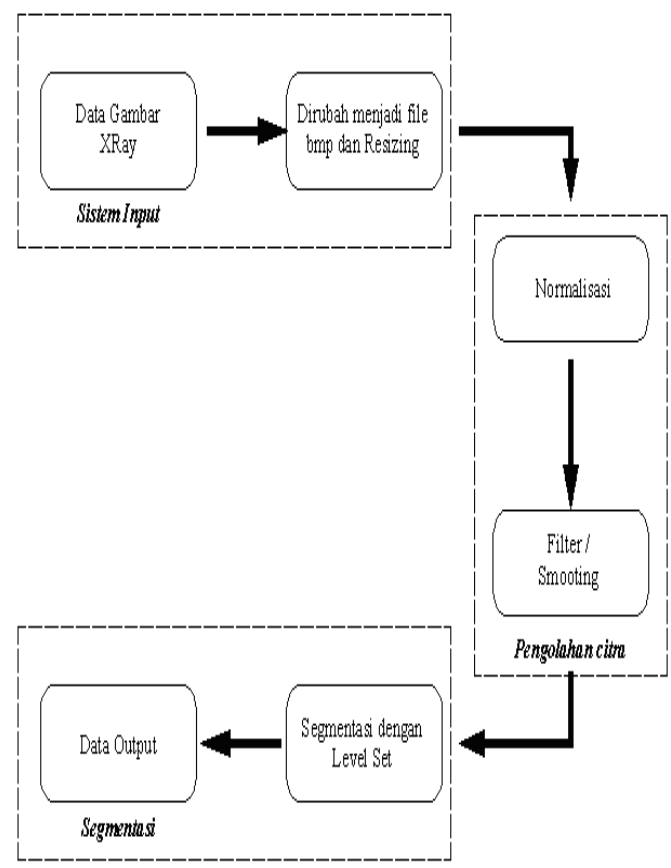

Gambar 1. Tahapan penelitian

\section{Eliminasi noise menggunakan Adaftive filtering}

Untuk meningkatkan kualitas citra dperlukan proses penghilangan noise, salah satu cara yang digunakan dengan adaftive filter. Sangat berguna adaftive filter untuk mengeliminasi piksel yang memiliki nilai ekstrim. Rumus yang digunakan sebagai berikut (Gonzales, 2004) :

$\mu=\frac{1}{N M} \sum_{n 1, n 2 \text { En }} \alpha\left(n_{1}, n_{12}\right)$

$\partial^{2}=\frac{1}{N M} \sum_{n 1, n 2 \in n} \alpha^{2}(n 1, n 2)-\mu^{2}$

$b\left(n_{1}, n_{2}\right)=\mu+\frac{\sigma^{z}-v^{2}}{\sigma^{2}}\left(\alpha\left(n_{1}, n_{2}\right)-\mu\right)$

\section{Contrast Enhancement}

Proses matching dari histogram diperlukan untuk meningkatkan kontras dari citra. Contrast enhancement menggunakan orthogonal transformation. Proses matching histogram diperlukan untuk meningkatkan kontras suatu citra, peningkatan kontras enhancement menggunakan metode transformasi orthogonal dari nilai intensitas citra, operasi ini dilakukan pada data dia area kecil bukan untuk seluruh area citra. Area yang ditingkatkan kontrasnya berdasarkan output area histogram (Chan, 1998).

Daerah-daerah mempunyai tetangga lalu digabungkan menggunakan interpolation bilinier, sehingga kontras dapat dibatasi -terutama pada bidang homogen untuk menghindari penguatan dari noise yang mungkin terjadi pada citra (Bowyer, 200).

\section{Closing}

Operasi morphology tertutup A terhadap B dilakukan dengan pembesaran notasi yang diteruskan dengan erosi, operasi morfologi tertutup untuk mendapatkan kontur dari obyek, menggabungkan patahan kecil (piksel yang hilang), mengisi lubang-lubang yang kecil dari piksel yang hilang berdasarkan struktur elemen yang ada. 


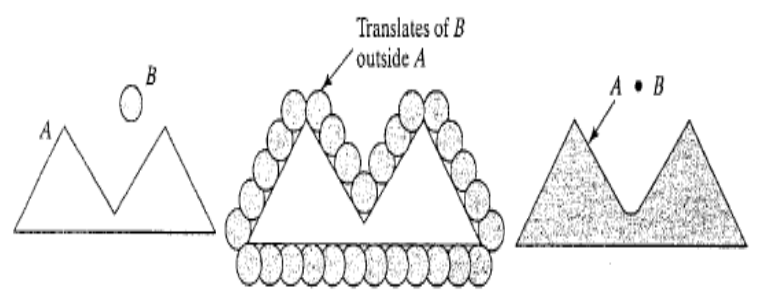

Gambar 2. ( a) Picture A dan Elemen Struktur B. (b) Friction terhadap B pada sisi A. ( c) Hasil dari operasi closing (Source: Gonzalez etal.: 2002:348)

\section{Active Contours}

Level Set merupakan metode untuk mendeteksi kurva yang bergerak, pertama kali dikenalkan oleh Stanley Osher dan J. Sethian pada tahun 1987. Persamaan dari Level Set $(\Psi)$ adalah :

$$
\Psi(x, t=0)= \pm d
$$

dimana $x$ adalah suatu posisi, $t$ adalah waktu dan $d$ adalah jarak dari $x$ terhadap kurva inisialisasi (distance). Kurva inisialisasi berupa sebuah lingkaran dengan titik pusat dan jari-jari tertentu. Posisi $x$ menentukan tanda $d$ (+ atau -), tanda $d$ diberi nilai positif bila $x$ menjauh titik pusat kurva inisialisasi atau diluar kurva inisialisasi, sebaliknya tanda $d$ diberi nilai negatif bila $x$ mendekat titik pusat kurva inisialisasi atau didalam kurva inisialisasi. Daerah antara nilai distance $(d)$ positif dan negatif inilah yang menunjukkan dimana kurva berada, ini yang membuat kurva dapat berbentuk cembung atau cekung (Chunming, 2005).

Level Set merupakan metode untuk mendeteksi kurva yang bergerak (or active contours), disimbolakan $C$, dengan representasi dari zero level set $C(t)=\{(x$, $y) \mid \varphi(t, x, y)=0\}$ dari fingsi level set $\varphi(t$, $x, y)$. Evolusi persamaan dari fungsi level set $\varphi$ sebagai berikut :

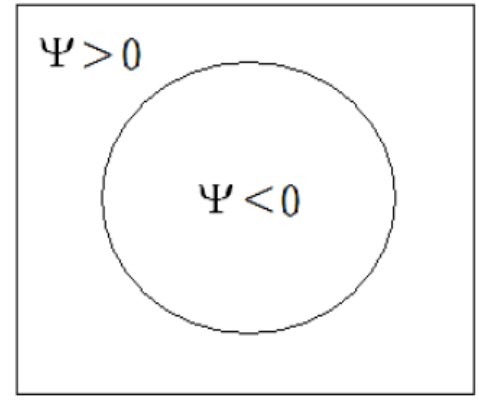

Gambar 3. Area distance

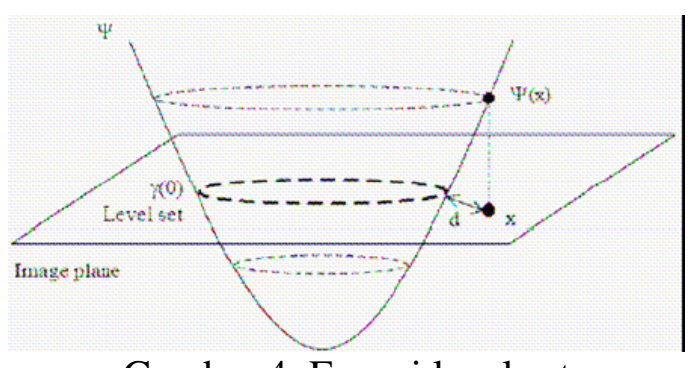

Gambar 4. Fungsi level set

Pada gambar 4. merupakan grafik fungsi level set, dimana Image plane adalah bidang gambar, sedangkan kurva yang berbentuk menyerupai gunung terbalik adalah fungsi level set.

Berdasarkan gambar 4. kurva berbentuk lingkaran yang mana titik di dalam kurva akan bernilai semakin kecil (negatif) bila berpuncak pada titik tengah lingkaran, sedangkan titik yang berada di luar kurva akan bernilai semakin besar apabila jaraknya semakin jauh dari kurva inisialisasi. Pada gambar tersebut ditunjukkan bagian kurva yang bertemu dengan bidang datar merupakan kurva inisialisasi $\Psi(x, t=0)$ atau zero level set.

Agar kurva dapat berevolusi maka dilakukan persamaan sebagai berikut :

$$
\Psi_{\mathrm{ij}}^{\mathrm{n}+1}=\Psi_{\mathrm{ij}}{ }^{\mathrm{n}}-\left.\Delta \mathrm{tF}\right|^{\nabla}{ }_{\mathrm{ij}} \Psi_{\mathrm{ij}}{ }^{\mathrm{n}} \mid
$$

sedangkan $t$ adalah waktu dan $F$ adalah speed function. $F$ mempunyai tiga faktor yang mempengaruhi pergerakan kurva yang dinyatakan dengan persamaan

$$
\mathrm{F}=\mathrm{F}_{\text {prop }}+\mathrm{F}_{\text {curv }}+\mathrm{F}_{\mathrm{adv}}
$$


$F_{\text {prop }}$ merupakan penambahan konstan kurva untuk bergerak searah dengan sudut normal, $\mathrm{F}_{\text {curv }}$ sebagai pengatur bentuk dari kurva, sedangkan $F_{\text {adv }}$ adalah faktor informasi dari gambar, sehingga Fprop dan Fcurv dapat dihitung dengan menggunakan persamaan berikut:

$$
\text { Fprop }+ \text { Fcurv }=1-\text { Ек }
$$

Dimana $\varepsilon$ konstanta bernilai antara 1 sampai 5 , semakin besar $\varepsilon$ semakin cepat kurva berevolusi, $\kappa$ merupakan kurva yang dapat dihitung dengan menggunakan persamaan berikut:

$$
K=\nabla \cdot \frac{\nabla \Psi}{|\nabla \Psi|}=-\frac{\Psi_{x x} \Psi_{y}^{2}-2 \Psi_{x} \Psi_{y} \Psi_{x y}+\Psi_{y y} \Psi_{y}^{2}}{\left(\Psi_{x}^{2}+\Psi_{y}^{2}\right)^{3 / 2}}
$$

\section{Dimana :}

$\Psi x$ turunan pertama $\Psi$ terhadap sumbu $x$, $\Psi x x$ turunan kedua $\Psi$ terhadap sumbu $x$, $\Psi y$ turunan pertama $\Psi$ terhadap sumbu $y$, $\Psi y y$ turunan kedua $\Psi$. terhadap sumbu $y$, $\Psi x y$ turunan $\Psi$ terhadap sumbu $x$ dan sumbu $y$.

Untuk menghitung masing-masing turunan digunakan pendekatan central difference yaitu:

$$
\begin{aligned}
& \Psi x=\Psi(x+1, y)-\Psi(x-1, y) / 2 \\
& \Psi x x=\Psi(x+1, y)-2 \Psi(x, y)+\Psi(x-1, y) \\
& \Psi y=\Psi(x, y+1)-\Psi(x, y-1) / 2 \\
& \Psi y y=\Psi(x, y+1)-2 \Psi(x, y)+\Psi(x, y-1) \\
& \Psi x y=\Psi(x+1, y+1)-\Psi(x-1, y+1)- \\
& \Psi(x+1, y-1)+\Psi(x-1, y-1) / 4
\end{aligned}
$$

Kemudian untuk menghitung persamaan $\quad F=$ Fprop + Fcurv + Fadv, hasil persamaan Fprop + Fcurv. tidak ditambahkan dengan Fadv melainkan dikalikan dengan KI (real positif) yang merupakan informasi border dari gambar, yang dinyatakan dengan persamaan ;

$$
\mathrm{F}=(\text { Fprop }+ \text { Fcurv }) *(\mathrm{KI})
$$

$$
\mathrm{KI}(\mathrm{x}, \mathrm{y})=\frac{}{1+\left.\right|^{\nabla} \mathrm{G} \sigma * I(\mathrm{x}, \mathrm{y}) \mid}
$$$$
1
$$

dimana ${ }^{\nabla} G \quad \sigma^{*} I(x, y)$ merupakan gradien dari Gaussian smoothing filter dengan karakteristik lebar $\sigma$. Nilai dari ${ }^{\nabla} G \sigma * I(x, y)$ biasanya bernilai positif kecil atau positif mendekati nol apabila tidak berada pada border dari citra, jika berada pada border maka nilainya akan sangat besar dan akan membuat nilai dari $\mathrm{K}_{\mathrm{I}}$ semakin kecil atau mendekati nol, sehingga evolusi kurva akan bernilai sangat kecil apabila berada pada border dari citra.

Nilai gradien maksimum diambil antara gradien yang terbesar antara gradien arah horisontal dan gradien arah vertikal. Jika gradien < threshold maka gradien dianggap 0 , hal ini akan mempengaruhi hasil segementasi yang disebabkan oleh penentuan harga threshold.

$$
\mathrm{KI}=1 /(1+\text { gradien })
$$

\section{HASIL}

Pada bagian ini akan dijabarkan evaluasi kinerja dari metode yang digunakan dalam mengatasi masalah segmentasi organ paru. Metode yang digunakan meliputi pengolahan citra, dengan tujuan untuk memberikan sebuah citra masukan yang bagus, smooth, dengan intensitas yang cukup. Dari citra yang ada dilakukan normalisasi dan proses smoothing dengan menggunakan spesial filter tipe gaussian lowpass filter. Setelah melalui proses smooting, dilakukan proses segmentasi dengan menggunakan active contour - level set. Kontur yang telah diinisialisasi akan berevolusi karena pengaruh dari energi internal yang menghitung simpangan pada fungsi level set dari fungsi jarak dan energi eksternal yang memicu pergerakan zero level set ke arah fitur image yang didinginkan(batas obyek / tepi gambar). 
Hasil evolusi dari fungsi level set adalah gradient flow dari image yang merupakan nilai minimal dari keseluruhan fungsi energi. Proses segmentasi dengan level set ini akan menghasilkan data output yang berupa contour / citra gray level.

Citra output yang diperoleh akan dievaluasi dengan cara membandingkannya dengan citra segmentasi manual sehingga diperoleh sebuah pengukuran kinerja metode yang digunakan untuk dibandingkan dengan beberapa metode yang telah ada sebelumnya.

Citra X-ray paru-paru, hasil pra prosesing dan hasil segmentasi dipaparkan pada gambar berikut:

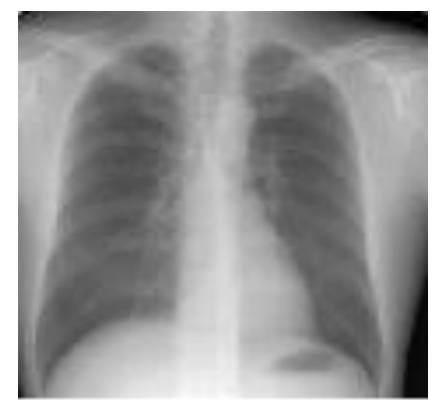

Gambar 5. Citra X-ray asli

Pada metode active contour, khususnya level set, inisialisasi contour awal merupakan tahap yang sangat berpengaruh pada proses evolusi dan hasil output yang diperoleh. Pada metode level set, inisialisasi contour awal yang semakin mendekati fitur obyek /edge, maka akan diperoleh output yang diharapkan dan jumlah evolusi /iterasi akan semakin pendek. Hal ini dapat dibuktikan pada gambar 6 dan 7 dengan parameter yang sama, output dan jumlah iterasi tergantung pada inisialisasi kontur awal.

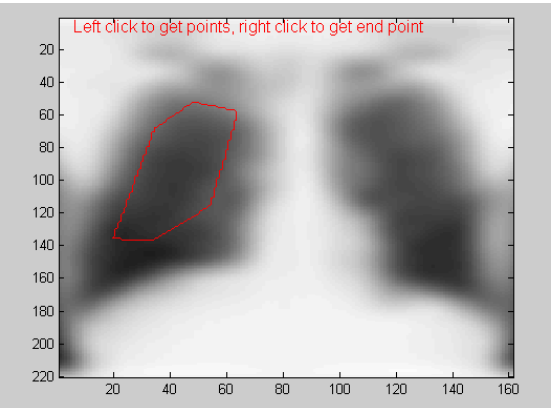

(a)

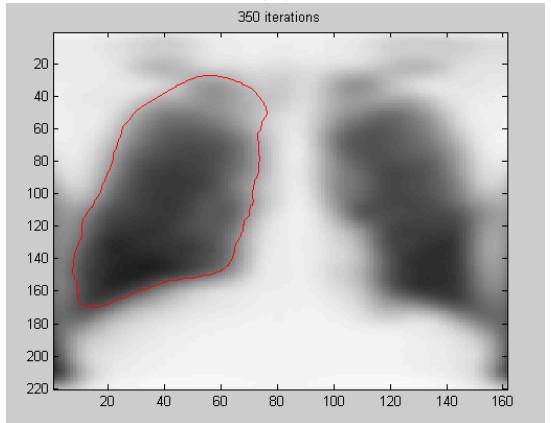

(b)

Gambar 6. (a) inisialisasi contour awal yang mendekati fitur obyek /edge (b) output pada iterasi ke 350 .

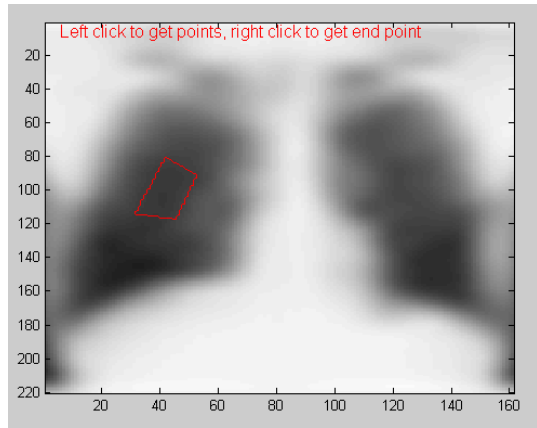

(a)

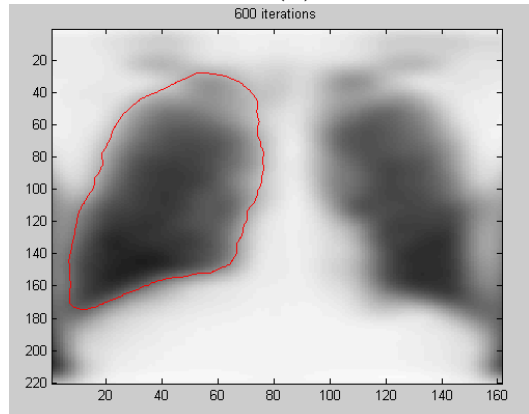

(b)

Gambar 7. (a) inisialisasi contour awal jauh dari fitur obyek/edge, (b) output pada iterasi ke 600 


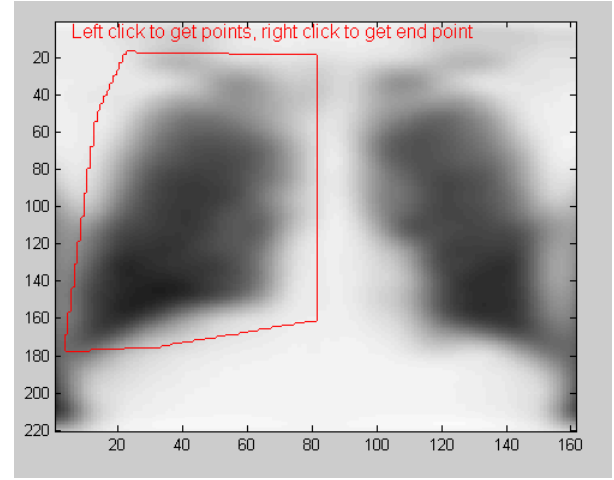

(a)

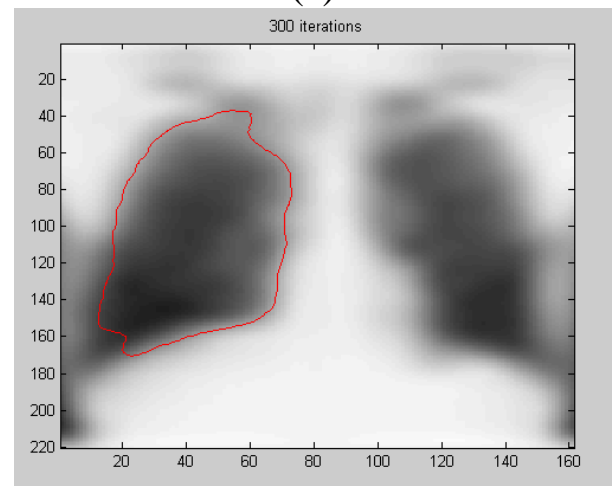

(b)

Gambar 4.7 (a) inisialisasi contour diluar obyek/edge, dan (b) output dari masing - masing inisialisasi

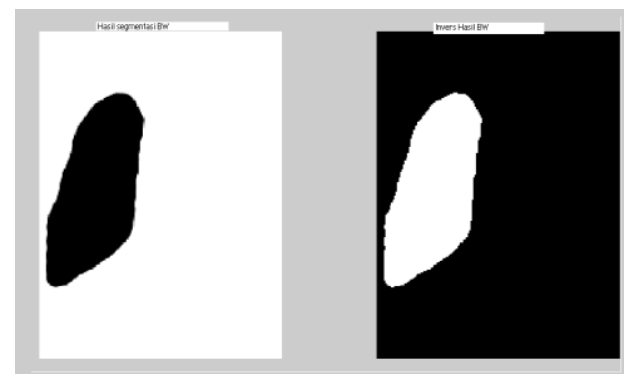

Gambar 8. Hasil segmentasi pada level black-white dan invers

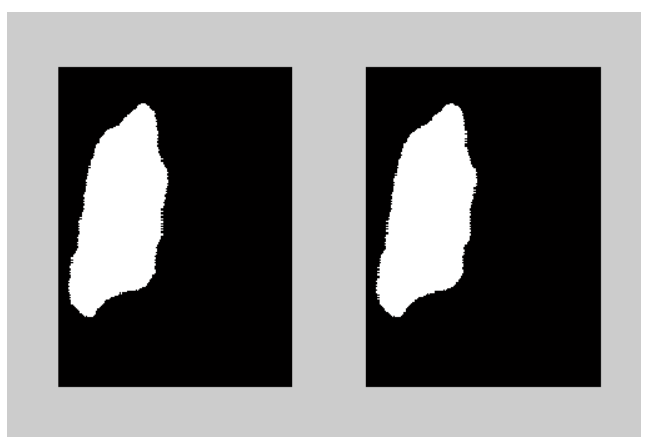

(a)

(b)

Gambar 9. (a) Hasil segmentasi paru-paru

(b) referensi manual paru-paru
Image yang digunakan pada proses segmentasi ini sebanyak 20. Dari hasil perhitungan tersebut tampak bahwa dengan menggunakan metode GVF snake, segmentasi yang dihasilkan pada paru-paru kanan mempunyai nilai rata-rata sensitifitas $73,28 \%$, akurasi $94,76 \%$ dan spesifitas $98,00 \%$, hal ini dapat dilihat pada tabel terlampir.

Tabel 1. Perbandingan data Akurasi,

Sensitifitas dan Spesifisitas dengan menggunakan metode level set dan GVF snake untuk paru-paru kanan

\begin{tabular}{|c|c|c|c|}
\hline Metode & $\begin{array}{c}\text { Sensitifitas } \\
(\%)\end{array}$ & $\begin{array}{c}\text { Akurasi } \\
(\%)\end{array}$ & $\begin{array}{c}\text { Spesifisitas } \\
(\%)\end{array}$ \\
\hline Level set & 93,47 & 95,88 & 96,31 \\
\hline $\begin{array}{c}\text { GVF } \\
\text { snake }\end{array}$ & 73,25 & 94,76 & 98,00 \\
\hline
\end{tabular}

Tabel 2. Perbandingan data

Akurasi,Sensitifitas dan Spesifisitas dengan menggunakan metode level set dan

GVF snake untuk paru-paru kiri

\begin{tabular}{|c|c|c|c|}
\hline Metode & $\begin{array}{c}\text { Sensitifitas } \\
(\%)\end{array}$ & $\begin{array}{c}\text { Akurasi } \\
(\%)\end{array}$ & $\begin{array}{c}\text { Spesifisitas } \\
(\%)\end{array}$ \\
\hline Level set & 93,23 & 96,18 & 96,79 \\
\hline $\begin{array}{c}\text { GVF } \\
\text { snake }\end{array}$ & 72,90 & 94,48 & 98,39 \\
\hline
\end{tabular}

Metode segmentasi dengan menggunakan active contour - level set dapat diaplikasikan untuk melakukan segmentasi citra X-RAY dengan tingkat akurasi yang tinggi.

Berdasarkan pada tingkat akurasi hasil segmentasi, maka hasil penelitian ini cukup akurat dan dapat digunakan sebagai alternative dalam melakukan segmentasi paru-paru pada citra X-RAY sebagai salah satu sarana untuk mendapatkan CTR.

\section{PEMBAHASAN}

Metoda Level set cocok digunakan untuk menganalisa bentuk citra geometri. Level set memiliki dua proses utama yaitu dilatasi dan erosi, kedua proses ini saling melengkapi atau menutupi dari pikselpiksel kombinasi dengan mekanisme yang 
khusus. Dua hal yang terpenting dalam transformasi ortogonal yaitu opening dan closing. Opening berarti membuka terjadinya erosi dan menunjukkan citra obyek dan erosi memperkecilnya. Opening pencarian kurva diluar obyak suatu citra. Closing pencarian kurva didalam obyek suatu citra.

\section{REFERENCES}

Bowyer K.W., M.H. Loew, H.S. Stiehl, and M.A. Viergever. Methodology of evaluation in medical image computing. In Rep. Dagstuhl Workshop, 2001.

Bruijne M. de, B. van Ginneken, W.J. Niessen, and M.A. Viergever. Adapting active shape models for $3 D$ segmentation of tubular structures in medical images. In Information Processing in Medical Imaging, volume 2732 of Lecture Notes in Computer Science, pages 136-147. Springer, 2003.

Canny J., A computational approach to edge detection, IEEE Transactions on Pattern Analysis and Machine Intell igence, vol. 8, no. 6, tahun 1986.

Carrascal F.M., J.M. Carreira, M. Souto, P.G. Tahoces, L. Gomez, J.J. Vidal., Automatic calculation of total lung capacity from automatically traced lung boundaries in postero-anterior and lateral digital chest radiographs, Medical Physics, vol. 25, no. 7, tahun 1998.

Chan D.C. \& W.R. Wu., Image contrast enhancement based on a histogram transformation of local standard deviation, IEEE Transactions on Medical Imaging, vol. 17, no. 4, tahun 1998.

Chan D.C. \& W.R. Wu., Image contrast enhancement based on a histogram transformation of local standard deviation, IEEE Transactions on Medical Imaging, vol. 17, no. 4, tahun 1998.

Chunming Li, Chenyang $\mathrm{Xu}$, Changfeng Gui, and Martin D. Fox, (2005), "Level Set Evolution Without Reinitialization: A New Variational Formulation",IEEE

Chunming Li, Chenyang Xu , Changfeng Gui , and Martin D. Fox., Level Set Evolution Without Re-initialization: A New Variational Formulation, Proceedings of the 2005 IEEE Computer Society Conference on Computer Vision and Pattern Recognition 2005.

Cocosco C. A., A. P. Zijdenbos, and A. C. Evans. A fully automatic and robust brain MRI tissue classification method. Medical Image Analysis, 7(4):513-527, 2003.

Dryden I. \& K.V. Mardia, The statistical analysis of shape, Wiley, London, 1998.

Ginneken Bram van, Computer aided diagnostic in chest Radiography : 9 maret 2001

Ginneken Bram van, Mikkel B. Stegmann, and Marco Loog, Segmentation of anatomical structures in chest radiographs using supervised methods: a comparative study on a public database, 11th August 2004

Gonzalez R. C., R. E. Woods, and S. L. Eddins (2004). Digital image processing using Matlab. Upper Saddle River, NJ: Pearson Prentice Hall. 
Gray Henry, Henry Gray's Anatomy of the Human Body, (Gray's Anatomy), nop 2004, 39 ${ }^{\text {th }}$. Britania.

Schilham Arnold M.R, Bram Van Ginneken, Marco Log., A computeraided diagnosis system for detection of lung nodules in chest radiographs with an evaluation on public database, Elsivier, February 2005. 